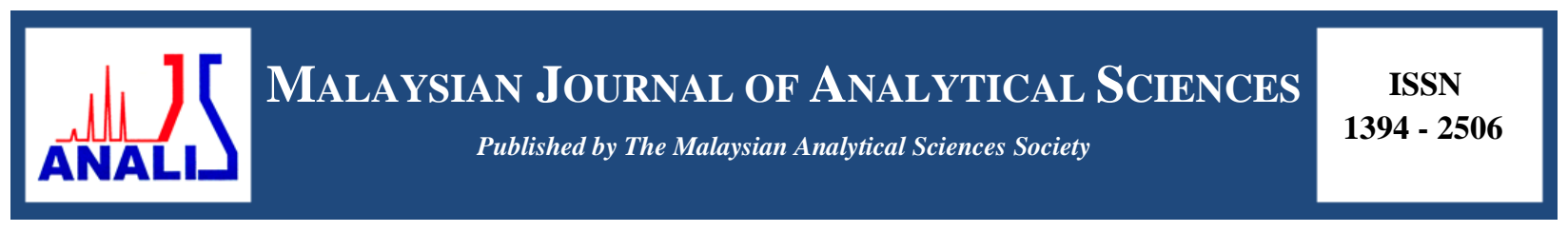

\title{
SYNTHESIS AND CHARACTERISATION OF $N$-ANALINEFERROCENYLAMIDE VIA CARBODIIMIDE COUPLING
}

\author{
(Sintesis dan Pencirian $N$-Analineferosenilamida melalui Gandingan Silang Karbodiimida) \\ Ken Min Liew ${ }^{1}$, Tei Tagg ${ }^{1}$, Wan M. Khairul ${ }^{1,2 *}$ \\ ${ }^{1}$ School of Fundamental Science \\ ${ }^{2}$ Advanced Nano Materials (ANoMa) Research Group, School of Fundamental Science \\ Universiti Malaysia Terengganu, 21030 Kuala Nerus, Terengganu, Malaysia \\ *Corresponding author: wmkhairul@umt.edu.my
}

Received: 24 February 2019; Accepted: 24 March 2019

\begin{abstract}
Ferrocene is an orthodox organometallic complex. This "sandwich compound" was found to have great flexibility in chemical reactions. The use of ferrocenyl derivatives branches into various interesting fields especially for biological applications. Derivatives of ferrocenylamides are of great interest in the field of medicine and biology researches, due to their ability to bind with various biomolecules, i.e. DNA. Thus, a simple yet effective method in the formation of ferrocenylamide derivatives is desirable. Ferrocene is stable in both aqueous and aerobic media, it also has a certain degree of resistance to thermal degradation, and hence the synthesis of ferrocenyl derivatives via carbodiimide coupling is possible. In this work, $N$-analineferrocenylamide was synthesised from 3-(ethyliminomethyleneamino)- $N, N$-dimethylpropan-1-amine (EDC) coupling of ferrocenecarboxylic acid and $p$-phenylenediamine. This synthesis approach is a simple and easy one-pot reaction without the need of tedious conditions and has a good product yield.
\end{abstract}

Keywords: ferrocene, amide, EDC coupling

\begin{abstract}
Abstrak
Ferosena merupakan kompleks organologam yang ortordoks. "Sebatian sandwich" ini didapati mempunyai pelbagai kebolehan di dalam tindakbalas kimia. Pengunaan terbitan-terbitan ferosena terjangkau di dalam pelbagai bidang yang menarik terutamanya dalam aplikasi biologi. Terbitan-terbitan ferosenilamida telah menarik minat yang mendalam dalam kajian bidang perubatan dan biologi, berdasarkan keupayaannya untuk terikat dengan pelbagai biomolekul seperti DNA. Justeru itu, kaedah yang ringkas dan efektif dalam pembentukan terbitan-terbitan ferosenilamida telah menjadi keutamaan. Ferosena adalah stabil di dalam kedua-dua media akues dan aerobik, ia juga mempunyai darjah keupayaan rintangan yang tertentu terhadap penguraian terma, yang telah memungkinkan sintesis terbitan-terbitan ferosena melalui gandingan silang karbodiimida. Di dalam kajian ini, $N$ analinaferosenilamida telah disintesiskan daripada gandingan silang 3-(etiliminometilenaamino)- $N, N$-dimetilpropan-1-amina (EDC) terhadap asid karboksilikferosena dan $p$-fenilenadiamina. Pendekatan sintesis adalah tindakbalas satu pot yang ringkas dan mudah tanpa memerlukan keadaan yang remeh dan berjaya menghasilkan hasilan yang baik.
\end{abstract}

Kata kunci: ferosena, amida, gantian silang EDC

\section{Introduction}

To date, the research on ferrocene and ferrocenyl derivatives are still advancing. Recent years, ferrocenyl derivatives are widely used in biological applications [1-10], material science [11] and catalysis [12-13]. Ferrocenyl amides were synthesised with various synthetic approaches in the previous occasions [14-19]. To the continuous 
effort of creating simpler approach to ferrocenyl amide synthesis, this work involves a simple approach with carbodiimide coupling. The selected coupling method requires the use of only one reacting vessel, with minimal agitation and at room temperature.

This project uses ferrocenecarboxylic acid and $p$-phenylenediamine as starting materials, leading to the final product by a modification of the very successful Steglich esterification. Steglich esterification was reported as very successful for bimolecular esterification at rather high dilutions [20], with the use of 3 10\% mol of 4-N,Ndimethylaminopyridine (DMAP) as homogenous organocatalyst. DMAP was used as "activator" for the coupling [21], to form a stable intermediate O-acylisourea [22] which resonates into a reactive species that significantly catalyse the coupling reaction.

\section{Materials and Methods}

All chemicals and solvents used in this study were obtained from standard commercial suppliers and used as received without further purification nor had treatment been carried out prior experimental works. Chemicals namely ethyl acetate (EA) and dichloromethane (DCM) were purchased from Fisher Scientific. In addition, chemicals namely $N, N$ '-dicyclohexylcarbodiimide (DCC), 3-(ethyliminomethyleneamino)- $N, N$-dimethylpropan-1amine (EDC), ferrocenecarboxylic acid, 4-(dimethylamino)pyridine and dimethyl sulfoxide- $\mathrm{d}_{6}\left(\mathrm{DMSO}-\mathrm{d}_{6}\right)$ were supplied by Sigma-Aldrich. While, chemicals namely anhydrous magnesium sulphate, silica gel 60 and ethanol were obtained from Merck. The FT-IR spectra were recorded using Perkin Elmer Spectrum 100 FT-IR Spectrometer 100 in the range of $4000-400 \mathrm{~cm}^{-1}$ using potassium bromide $(\mathrm{KBr})$ pellets. ${ }^{1} \mathrm{H}$ NMR were recorded in DMSO- $\mathrm{d}_{6}$ using Bruker Avance III $700 \mathrm{MHz}$ at room temperature in the range between $\delta_{\mathrm{H}} 0-15 \mathrm{ppm}$. DFT calculations were performed with Gaussian 09 (version B.01) package [23].

\section{Synthesis of $N$-analineferrocenylamide through DCC coupling}

Synthesis approach for this compound was a modified method from an esterification reported by Srinivas et al. [24]. $N$-analineferrocenylamide was prepared by esterification between $4.35 \mathrm{mmol}$ of ferrocenecarboxylic acid and $6.53 \mathrm{mmol}$ of $p$-phenylenediamine (excess reagent), catalysed by $10 \% \quad(0.44 \mathrm{mmol})$ DMAP. $N, N^{\prime}-$ dicyclohexylcarbodiimide (DCC) of ratio 1:1 to the reagents was employed as the coupling agent. 1.0M DCC solution in methylene chloride was mixed in to a septum secured nitrogen purged round bottom flask, with the two solid reagents and a magnetic stir bar already mixed in. The DCC solution is kept as dry and clean as possible by transferring with a steel syringe needle. $50 \mathrm{~mL}$ of anhydrous dichloromethane was then transferred into the flask by cannula transfer at $4^{\circ} \mathrm{C}$ with the help of ice bath. The solution matrix was then immediately mixed using a magnetic stirrer for $6 \mathrm{~h}$ at a temperature ideally kept below $10^{\circ} \mathrm{C}$, then another $72 \mathrm{~h}$ at room temperature. Reaction mixture was filtered after the $72 \mathrm{~h}$, the crude deep orange filtrate was purified by silica gel $\left(\mathrm{SiO}_{2}\right)$ column (ethyl acetate: dichloromethane $=1: 9$ ), to yield a bright orange precipitate.

\section{Synthesis of $\mathrm{N}$-analineferrocenylamide through EDC coupling}

The synthesis setup and steps were completely identical to that of DCC coupling described above, except for replacing the liquid $\mathrm{DCC}$ with solid $\mathrm{EDC} \cdot \mathrm{HCl}$, the $\mathrm{EDC} \cdot \mathrm{HCl}$ crystals was directly mixed in together with $4.35 \mathrm{mmol}$ of ferrocenecarboxylic acid and $6.53 \mathrm{mmol}$ of $p$-phenylenediamine. The reaction matrix was directly fed into a silica gel $\left(\mathrm{SiO}_{2}\right)$ column (ethyl acetate: dichloromethane $\left.=1: 9\right)$, to yield a bright orange precipitate.

\section{DFT optimisation and frequency calculation}

The DFT calculation was performed by using B3LYP as hybrid functional. GEN was used as keyword to specify basis sets 6-31G(d,p) on the atoms C, H, O and N; DGaussDZVP [25] on the atom Fe.

\section{Spectroscopic data of $\mathrm{N}$-analineferrocenylamide}

\section{Results and Discussion}

${ }^{1} \mathrm{H}$ NMR $\left(700 \mathrm{MHz}, \mathrm{DMSO}-\mathrm{d}_{6}\right): \delta 4.21\left(\mathrm{~s}, 5 \mathrm{H}, \mathrm{C}_{5} \mathrm{H}_{5}\right) ; 4.39\left(\mathrm{t},{ }^{3} \mathrm{~J}_{H H}=4 \mathrm{~Hz}, 2 \mathrm{H}, \beta-\mathrm{C}_{5} \mathrm{H}_{4}\right) ; 4.88(\mathrm{~s}, 2 \mathrm{H}, \mathrm{NH}) ; 4.94(\mathrm{t}$, $\left.{ }^{3} \mathbf{J}_{H H}=4 \mathrm{~Hz}, 2 \mathrm{H}, \alpha-\mathrm{C}_{5} \mathrm{H}_{4}\right) ; 6.54\left(\mathrm{p}-\mathrm{d},{ }^{2} \mathbf{J}_{H H}=8 \mathrm{~Hz}, 2 \mathrm{H}, \mathrm{Ar}\right) ; 7.27\left(\mathrm{p}-\mathrm{d},{ }^{2} \mathbf{J}_{H H}=8 \mathrm{~Hz}, 2 \mathrm{H}, \mathrm{Ar}\right), 9.10(\mathrm{~s}, 1 \mathrm{H}, \mathrm{NH}) . \mathrm{IR}$ (KBr): v(N-H, secondary) $3422 \mathrm{~cm}^{-1} ; v\left(\mathrm{~N}-\mathrm{H}\right.$, secondary) $3445 \mathrm{~cm}^{-1} ; \mathrm{v}\left(\mathrm{N}-\mathrm{H}\right.$, primary) $3373 \mathrm{~cm}^{-1} ; v(\mathrm{C}=\mathrm{C}, \mathrm{Ar}) 1647$ $\mathrm{cm}^{-1}, 1544 \mathrm{~cm}^{-1} ; v\left(\mathrm{C}=\mathrm{O}\right.$, amide) $1606 \mathrm{~cm}^{-1}, 1544 \mathrm{~cm}^{-1}, v\left(\mathrm{C}-\mathrm{N}\right.$, secondary) $1404 \mathrm{~cm}^{-1}, 1313 \mathrm{~cm}^{-1}$. From the ${ }^{1} \mathrm{H}$ NMR of $N$-analineferrocenylamide, protons of the primary amine $\left(\mathrm{H}_{7}\right)$ appear as a singlet at $\delta_{\mathrm{H}} 4.88 \mathrm{ppm}$, the deshielding 
effect can be accounted to the diamagnetic anisotropy generated from circulating $\pi$-electrons of neighbouring phenyl ring [26]. The para-disubstituted benzene $\left(\mathrm{H}_{5}\right.$ and $\left.\mathrm{H}_{6}\right)$ shows a typical AA'BB' pattern when expanded, due to the protons on the opposite sides of the ring are not magnetically equivalent, portraying a second order splitting. Both resonance and negativity effect of oxygen depletes the electron density on the proton $\mathrm{H}_{4}$, leading to a deshielding effect, explains the very downfield $\mathrm{H}_{4}$ compare to $\mathrm{H}_{7}$ despite both being a proton attaching to a nitrogen atom. Furthermore, $\mathrm{H}_{4}$ is highly possible to participate in hydrogen bonding, which further deshields the proton, much downfield compare to the typical 5.0-8.0ppm region of amides. $\mathrm{H}_{4}$ appears as singlet at $\delta_{\mathrm{H}} 9.10 \mathrm{ppm}$, a ferrocenylamide was reported previously to show a signal at $\delta_{\mathrm{H}} 8.44 \mathrm{ppm}$, while phenylamide appeared at $\delta_{\mathrm{H}} 9.07$ ppm [27]. Meanwhile, $\mathrm{Fc}-\mathrm{H}_{\alpha}, \mathrm{Fc}-\mathrm{H}_{\beta}$ and $\mathrm{Fc}_{-} \mathrm{C}_{5} \mathrm{H}_{5}$ show a typical $\mathrm{A}_{2} \mathrm{~B}_{2}$ splitting pattern in their NMR profiles, the cyclopentadienyl of some ferrocenyl amides also reported to have the same chemical shift region of $4.01 \mathrm{ppm}$ to $4.70 \mathrm{ppm}[29]$.

In the IR spectrum of $N$-analineferrocenylamide, the bands at $3422 \mathrm{~cm}^{-1}, 3445 \mathrm{~cm}^{-1}$ and $1544 \mathrm{~cm}^{-1}$ correspond to stretching and bending of $\mathrm{N}-\mathrm{H}$ bonding present in the molecule. Some ferrocenyl derivatives have shown a $\mathrm{NH}$ bending at frequency of $3100 \mathrm{~cm}^{-1}$ to $3300 \mathrm{~cm}^{-1}$ [30]. Both secondary and primary amine stretching were observed in the spectrum in bands of medium intensity, in well agreement with the proposed structure. The typical bands for aromatic $\mathrm{C}=\mathrm{C}$ is observed as a couple of $1605 \mathrm{~cm}^{-1}$ and $1544 \mathrm{~cm}^{-1}$. A strong absorption at $1647 \mathrm{~cm}^{-1}$ shows the presence of $\mathrm{C}=\mathrm{O}$, highly possible from an amide. A few reported ferrocenyl amides had shown a $\mathrm{C}=\mathrm{O}$ stretching at around $1600 \mathrm{~cm}^{-1}[15,31-33]$. At the fingerprint region, a couple of $\mathrm{C}-\mathrm{H}$ and $\mathrm{N}-\mathrm{H}$ out-of-plane (oop) bending is observed at $824 \mathrm{~cm}^{-1}$ and $747 \mathrm{~cm}^{-1}$ respectively, further supports the presence of para-substituted aromatic C-H $[34,35]$ and $\mathrm{NH}$ groups [36] in the molecule.

\section{DFT calculations}

The DFT calculations do not involve any geometry constraint, no solvent optimisation, in gas phase. Table 1 shows the selected geometric parameters obtained. The data obtained are in good agreement compared to a published crystallography data of similarly structured ferrocenyl amide, namely (4-Ferrocenylphenyl)benzamide [37]. Bond lengths of the centre $\mathrm{Fe}$ atom to different carbon atoms from the substituted cyclopentadienyl ring are reported to be $2.034 \AA, 2.030 \AA, 2.028 \AA, 2.039 \AA$ and $2.059 \AA$ respectively, with the greatest bond length among the five being the one attached to a substituent group. However, in the DFT calculations, the C4 that attaches to a substituent group has a shortest bond length of $2.075 \AA$ to Fe. This might be due to the substituent group in the reported molecule is an electron donating benzene group, but the substituent of $\mathrm{N}$-analineferrocenylamide at $\mathrm{C} 4$ is an electron withdrawing carbonyl group. The bond angles reported are in similar trend to the calculated bond angles, being $40.81^{\circ}, 68.11^{\circ}$ and $68.32^{\circ}$ for one, two, three adjacent carbon spacing.

Table 1. Selected parameters from results obtained in DFT optimisation

\begin{tabular}{lcc}
\hline Corresponding Atoms & Bond Length $(\AA)$ & Bond Angle $\left(^{\mathbf{o}}\right)$ \\
\hline $\mathrm{C} 1-\mathrm{Fe}$ & 2.086 & - \\
$\mathrm{C} 2-\mathrm{Fe}$ & 2.086 & - \\
$\mathrm{C} 3-\mathrm{Fe}$ & 2.076 & - \\
$\mathrm{C} 4-\mathrm{Fe}$ & 2.075 & - \\
$\mathrm{C} 5-\mathrm{Fe}$ & 2.078 & - \\
$\mathrm{C} 1-\mathrm{Fe}-\mathrm{C} 2$ & - & 40.11 \\
$\mathrm{C} 1-\mathrm{Fe}-\mathrm{C} 3$ & - & 67.44 \\
$\mathrm{C} 1-\mathrm{Fe}-\mathrm{C} 4$ & - & 67.47 \\
$\mathrm{C} 1-\mathrm{Fe}-\mathrm{C} 13$ & - & 112.8 \\
\hline
\end{tabular}




\section{Synthesis approach}

The yields from DCC and EDC coupling are 56\% and 63\% respectively. The primary difference of product matrix in the two different couplings are DCC coupling produces a large amount of precipitate, while EDC coupling produces little to no precipitate. The precipitate is a typical by-product of DMAP catalysed DCC coupling, $N, N^{\prime}$ dicyclohexylurea (DCU) [38]. DCU is insoluble in most solvents including DCM and EA, which enables it to be separated through filtration.

On the other hand, EDC coupling produces a soluble urea, 3-(3-ethylureido)-N.N-dimethyl-1-propanaminium chloride as by-product. Separation of desired ferrocenyl amide from the two different coupling methods does not have much different, only filtering prior to column chromatography is required for DCC coupling. Thus, the slight difference in yield could be accounted to the multiple filtering attempt in removing DCU before the column chromatography. Furthermore, spikes of DCU were constantly observed in the NMR profile of $N$ analineferrocenylamide in the range of 1-2ppm. Ultimately, the synthesis was repeated by replacing DCC with $\mathrm{EDC} \cdot \mathrm{HCl}$, which is known to be a water-soluble good alternative for carbodiimide coupling [39]. The product separation after EDC coupling is straight forward, effective and much lesser solvent consumption.

A mechanism was proposed for this synthesis referring to a few studies done previously [22,40,41]. After the nucleophilic attack from DMAP and expel of the urea leaving group shown in Scheme 1 and Scheme 2, a reactive intermediate $\mathrm{O}$-acylisourea is formed. This intermediate is resonance stabilised, which enables it to exist for enough time to undergo nucleophilic attack, while reactive enough to be fully converted into end products [40,43,44]. The intermediate undergoes further nucleophilic attack from $p$-phenylenediamine to form the desired amide, as shown in Scheme 3.

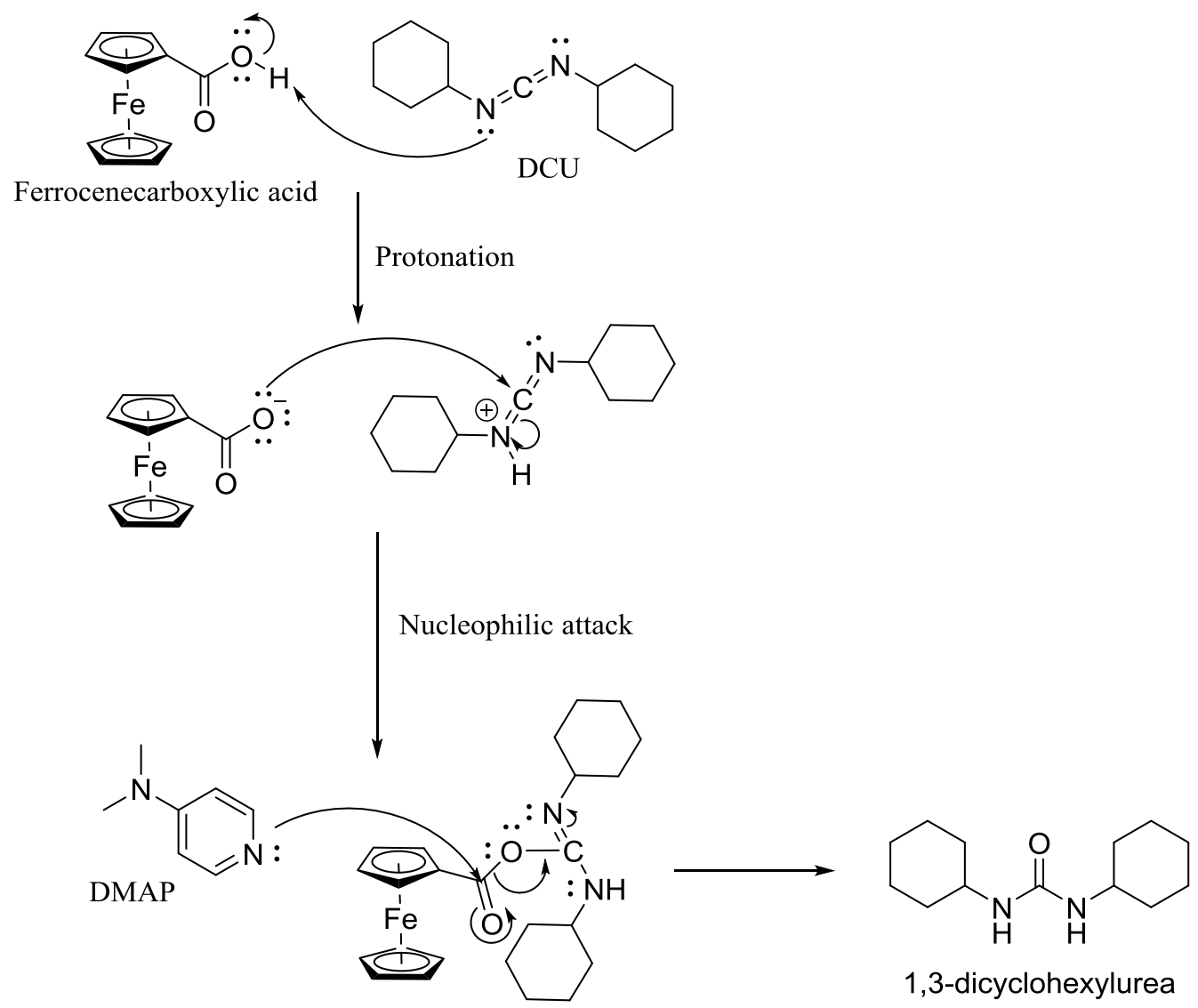

Scheme 1. Proposed mechanism of by-product formation in DCC coupling 


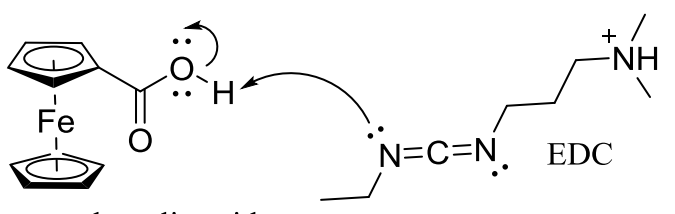

ferrocenecarboxylic acid
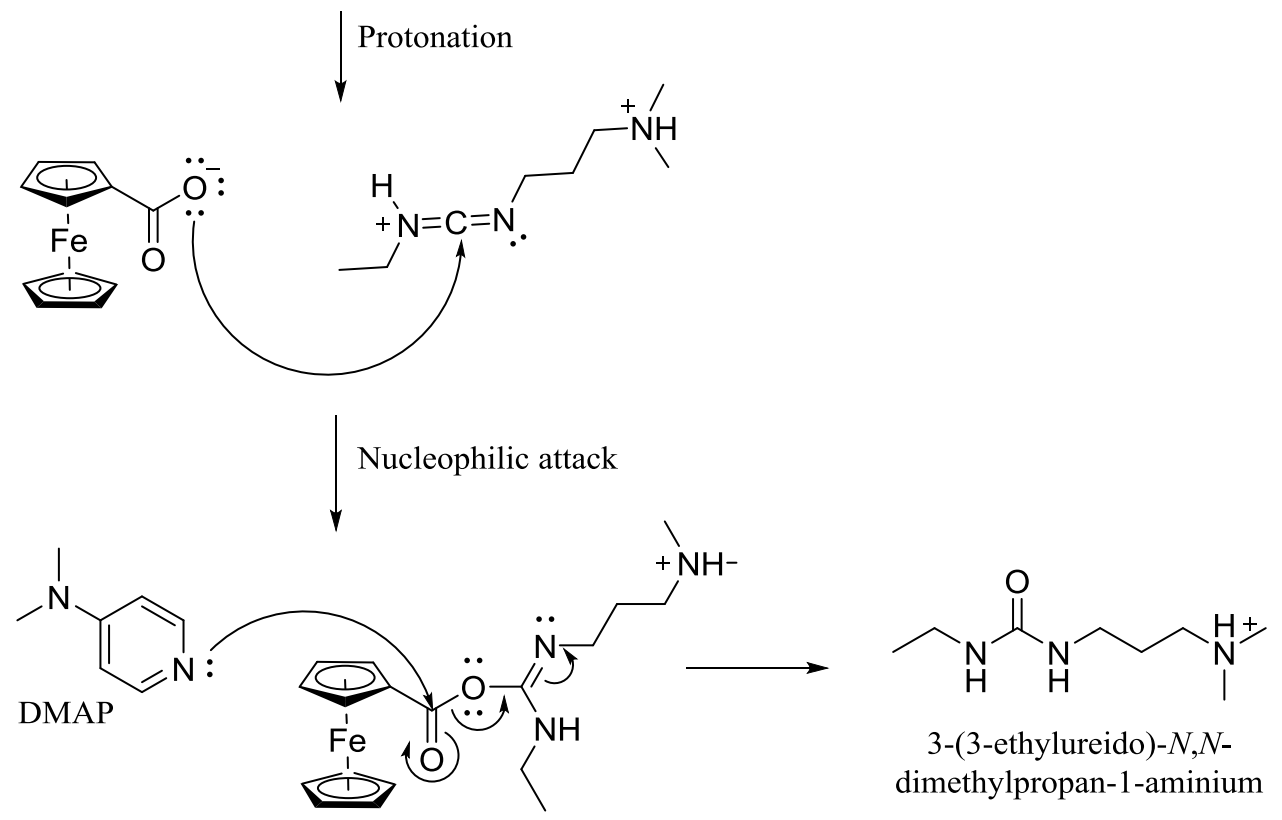

Scheme 2. Proposed mechanism of by-product formation in EDC coupling

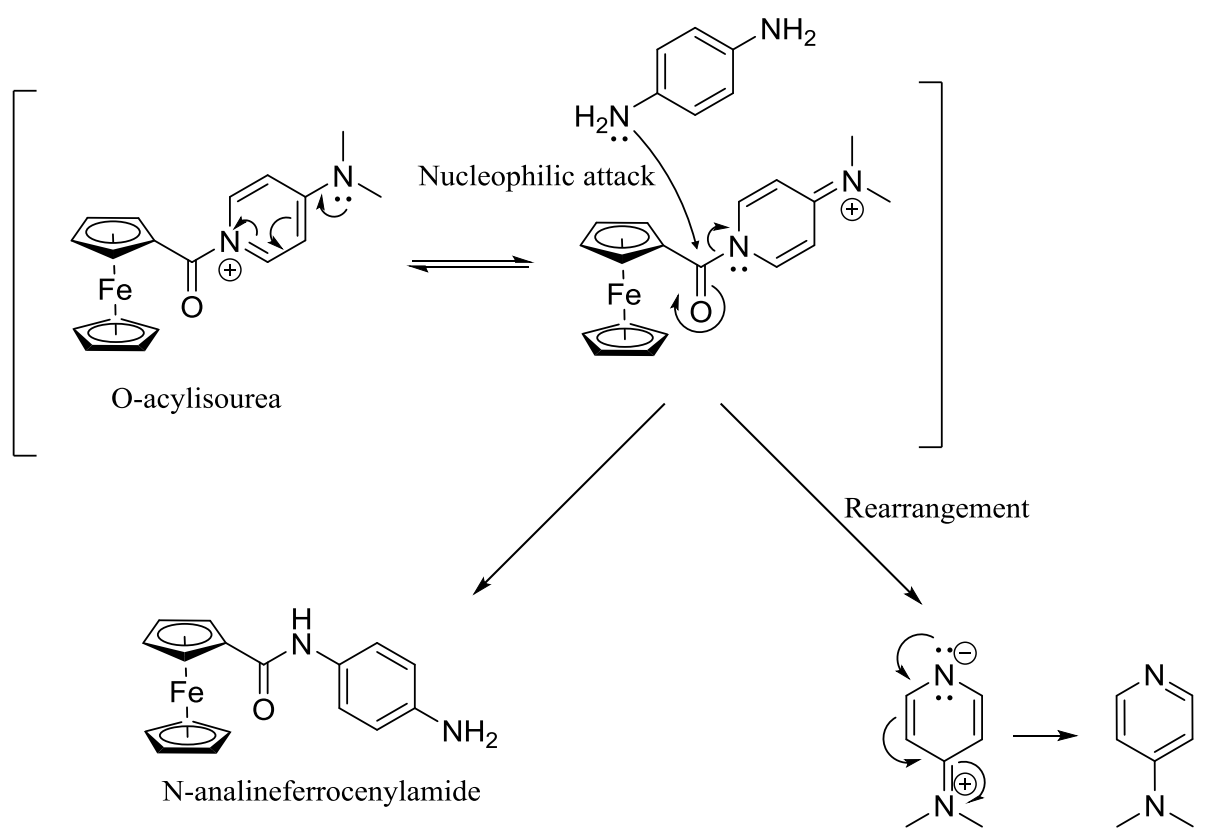

Scheme 3. Formation of $\mathrm{N}$-analineferrocenylamide from $\mathrm{O}$-acylisourea 


\section{Ken et al: SYNTHESIS AND CHARACTERISATION OF N-ANALINEFERROCENYLAMIDE VIA CARBODIIMIDE COUPLING}

Overall, carbodiimide coupling is very effective, simple and adequate for the synthesis of ferrocenyl amide, i.e. $\mathrm{N}$ analineferrocenylamide. A good yield of $63 \%$ was observed via EDC coupling.

\section{Conclusion}

At current stage of the study, we have demonstrated an efficient EDC coupling for the synthesis of ferrocenyl amide. Advantages of this synthesis are simple separation, one-pot reaction and relatively less tedious conditions. We anticipate that the same synthesis method could be used for the synthesis of other larger or more complex ferrocenyl amides.

\section{Acknowledgement}

The authors would like to acknowledge Ministry of Education Malaysia (MOE) for its Fundamental Research Grant Scheme (FRGS 59410), Institute of Genome Malaysia and Universiti Malaysia Terengganu for research facilities provided. We also would like to express our gratitude to MOE (Higher Education) for MyBrainSc Scholarship in supporting our postgraduate student's studies.

\section{References}

1. Singh, A., Saha, S. T., Perumal, S., Kaur, M. and Kumar, V. (2018). Azide-alkyne cycloaddition en route to $1 \mathrm{H}-1,2,3$-triazole-tethered isatin-ferrocene, ferrocenylmethoxy-isatin, and isatin-ferrocenylchalcone conjugates: synthesis and antiproliferative evaluation. ACS Omega, 3(1): 1263 - 1268.

2. Vashisht Gopal, Y. N., Jayaraju, D. and Kondapi, A. K. (2000). Topoisomerase II poisoning and antineoplastic action by DNA-nonbinding diacetyl and dicarboxaldoxime derivatives of ferrocene. Archives of Biochemistry and Biophysics, 376(1): 229 - 235.

3. Altaf, A. A., Lal, B., Badshah, A., Usman, M., Chatterjee, P. B., Huq, F., Ullah, S. and Crans, D. C. (2016). Synthesis, structural characterization, modal membrane interaction and anti-tumor cell line studies of nitrophenyl ferrocenes. Journal of Molecular Structure, 1113: 162 - 170.

4. Hodík, T., Lamač, M., Červenková Št’astná, L., Cuřínová, P., Karban, J., Skoupilová, H., Hrstka, R., Císařová, I., Gyepes, R. and Pinkas, J. (2017). Improving cytotoxic properties of ferrocenes by incorporation of saturated N-heterocycles. Journal of Organometallic Chemistry, 846: 141 - 151.

5. Lippert, R., Shubina, T. E., Vojnovic, S., Pavic, A., Veselinovic, J., Nikodinovic-Runic, J., Stankovic, N., and Ivanović-Burmazović, I. (2017). Redox behavior and biological properties of ferrocene bearing porphyrins. Journal of Inorganic Biochemistry, 171: $76-89$.

6. Narváez-Pita, X., Rheingold, A. L., Meléndez, E. (2017). Ferrocene-steroid conjugates: Synthesis, structure and biological activity. Journal of Organometallic Chemistry, 846: 113 - 120.

7. Pérez, W. I., Soto, Y., Ortíz, C., Matta, J. and Meléndez, E. (2015). Ferrocenes as potential chemotherapeutic drugs: Synthesis, cytotoxic activity, reactive oxygen species production and micronucleus assay. Bioorganic \& Medicinal Chemistry, 23(3): $471-479$.

8. Sarkar, T., Banerjee, S., Mukherjee, S., Hussain, A. (2016). Mitochondrial selectivity and remarkable photocytotoxicity of a ferrocenyl neodymium(iii) complex of terpyridine and curcumin in cancer cells. Dalton Transactions, 45(15): $6424-6438$.

9. Muenzner, J. K., Ahmad, A., Rothemund, M., Schrüfer, S., Padhye, S., Sarkar, F. H., Schobert, R., Biersack, B. (2016). Ferrocene-substituted 3,3'-diindolylmethanes with improved anticancer activity. Applied Organometallic Chemistry, 30(6): $441-445$.

10. Takarada, J. E., Guedes, A. P. M., Correa, R. S., Silveira-Lacerda, E. de P., Castelli, S., Iacovelli, F., Deflon, V. M., Batista, A. A. and Desideri, A. (2017). Ru/Fe bimetallic complexes: Synthesis, characterization, cytotoxicity and study of their interactions with DNA/HSA and human topoisomerase IB. Archives Biochemistry and Biophysics, 636: $28-41$.

11. Kulbaba, K. and Manners, I. (2001). Polyferrocenylsilanes: Metal-containing polymers for materials science, self-assembly and nanostructure applications. Macromolecular rapid communications, 22(10): $711-724$.

12. Butsugan, Y., Araki, S. and Watanabe, M. (1995). Ferrocenes 3 enantioselective addition of dialkylzinc to aldehydes catalyzed by chiral ferrocenyl aminoalcohols. Ferrocenes: Homogeneous Catalysis, Organic Synthesis, Materials Science, 143 - 168. 
13. Taei, M., Hasanpour, F. and Zahedi, G. (2015). Application of new ferrocene derivative for electrocatalytic determination of captopril using multiwall carbon nanotube modified carbon paste electrode. Bulletin of Chemical Society Ethiopia, 29(1): 149 - 156.

14. Ferreira, C. L., Ewart, C. B., Barta, C. A., Little, S., Yardley, V., Martins, C., Polishchuk, E., Smith, P. J., Moss, J. R., Merkel, M., Adam, M. J. and Orvig, C. (2006). Synthesis, structure, and biological activity of ferrocenyl carbohydrate conjugates. Inorganic Chemistry, 45(20): 8414 - 8422.

15. Zhao, M., Shao, G.-K., Huang, D.-D., Lv, X.-X. and Guo, D.-S. (2017). Synthesis, crystal structures and properties of ferrocenyl bis-amide derivatives yielded via the ugi four-component reaction. Molecules, 22 (5): 737.

16. Akbarzadeh, R., Mirzaei, P. and Bazgir, A. (2010). A simple synthesis of ferrocenyl bis-amides by a ugi fourcomponent reaction. Journal of Organometallic Chemistry, 695(21):, 2320 - 2324.

17. Ekti, S. F. and Hür, D. (2008). Microwave assisted synthesis of ferrocene amides. Inorganic Chemistry Communications, 11(9): 1027 - 1029.

18. Huang, X.-F., Tang, J.-F., Ji, J.-L., Wang, X.-L. and Ruan, B.-F. (2012). Synthesis, characterization and antitumor activity of novel amide derivatives containing ferrocenyl pyrazol-moiety. Journal of Organometallic Chemistry, 706-707: 113 - 123.

19. Huang, X. F., Wang, L. Z., Tang, L., Lu, Y. X., Wang, F., Song, G. Q. and Ruan, B. F. (2014). Synthesis, characterization and antitumor activity of novel ferrocene derivatives containing pyrazolyl-moiety. Journal of Organometallic Chemistry, 749: $157-162$.

20. Boden, E. P. and Keck, G. E. (1985). Proton-Transfer Steps in Steglich Esterification: A Very Practical New Method for Macrolactonization. Journal of Organic Chemistry, 50 (13): 2394 - 2395.

21. Pon, R. T. (1987). Enhanced coupling efficiency using 4-dimethylaminopyridine (DMAP) and either tetrazole, 5-(o-nitrophenyl) tetrazole, or 5-(p-nitrophenyl) tetrazole in the solid phase synthesis of oligoribonucleotides by the phosphoramidite procedure. Tetrahedron Letters, 28(32): 3643 - 3646.

22. Montalbetti, C. A. G. N. and Falque, V. (2005). Amide bond formation and peptide coupling. Tetrahedron, 61(46): $10827-10852$.

23. Frisch, M. J., Trucks, G. W., Schlegel, H. B., Scuseria, G. E., Robb, M. A., Cheeseman, J. R., Scalmani, G., Barone, V., Petersson, G. A., Nakatsuji, H., Li, X., Caricato, M., Marenich, A. V., Bloino, J., Janesko, B. G., Gomperts, R., Mennucci, B., Hratchian, H. P., Ortiz, J. V., Izmaylov, A. F., Sonnenberg, J. L., WilliamsYoung, D., Ding, F., Lipparini, F., Egidi, F., Goings, J., Peng, B., Petrone, A., Henderson, T., Ranasinghe, D., Zakrzewski, V. G., Gao, J., Rega, N., Zheng, G., Liang, W., Hada, M., Ehara, M., Toyota, K., Fukuda, R., Hasegawa, J., Ishida, M., Nakajima, T., Honda, Y., Kitao, O., Nakai, H., Vreven, T., Throssell, K., Montgomery, J. A., Jr., Peralta, J. E., Ogliaro, F., Bearpark, M. J., Heyd, J. J., Brothers, E. N., Kudin, K. N., Staroverov, V. N., Keith, T. A., Kobayashi, R., Normand, J., Raghavachari, K., Rendell, A. P., Burant, J. C., Iyengar, S. S., Tomasi, J., Cossi, M., Millam, J. M., Klene, M., Adamo, C., Cammi, R., Ochterski, J. W., Martin, R. L., Morokuma, K., Farkas, O., Foresman, J. B., Fox, D. J. (2016) Gaussian 16 Revision B.01. Gaussian Inc.: Wallingford CT 2016.

24. Srinivas, P., Prabhakar, S., Chevallier, F., Nassar, E., Erb, W., Dorcet, V., Jouikov, V., Radha Krishna, P. and Mongin, F. (2016). Synthesis of ferrocene amides and esters from aminoferrocene and 2-substituted ferrocenecarboxylic acid and properties thereof. New Journal of Chemistry, 40(11): 9441 - 9447.

25. Sosa, C., Andzelm, J., Elkin, B. C., Wimmer, E., Dobbs, K. D. and Dixon, D. A. (1992). A local density functional study of the structure and vibrational frequencies of molecular transition-metal compounds. The Journal of Physical Chemistry, 96(16): 6630 - 6636.

26. Pavia, D. L., Lampman, G. M., Kriz, G. S. and Vyvyan, J. R. (2015). Introduction to Spectroscopy, Fifth Edition. Cengage Learning Asia, Singapore: pp. 390 - 397.

27. Kuo, L. J., Liao, J. H., Chen, C. T., Huang, C. H., Chen, C. S. and Fang, J. M. (2003). Two-arm ferrocene amide compounds: Synclinal conformations for selective sensing of dihydrogen phosphate ion. Organic Letters, 5(11): $1821-1824$.

28. Kienz, T., Förster, C. and Heinze, K. (2014). Impact of O $\rightarrow$ S exchange in ferrocenyl amides on the structure and redox chemistry. Organometallics, 33(18), $4803-4812$.

29. Carty, P., Grant, J. and Simpson, A. (1988) Synthesis of a novel ferrocene derivative having flame-retardant and smoke-suppressant properties. Applied Organometallic Chemistry, 2(3): 277 - 280. 
30. N'Da David, D., Breytenbach Jaco, C., Smith Peter, J. and Lategan, C. (2010). Synthesis, cytotoxicity and antimalarial activity of ferrocenyl amides of 4-aminoquinolines. Arzneimittelforschung, 60(10), $627-635$.

31. Javed, F., Altaf, A. A., Badshah, A., Tahir, M. N., Siddiq, M., Zia-Ur-Rehman, Shah, A., Ullah, S. and Lal, B. (2012). New supramolecular ferrocenyl amides: synthesis, characterization, and preliminary DNA-binding studies. Journal of Coordination Chemistry, 65(6): 969 - 979.

32. Siebler, D., Linseis, M., Gasi, T., Carrella, L. M., Winter, R. F., Förster, C. and Heinze, K. (2011). Oligonuclear ferrocene amides: Mixed-valent peptides and potential redox-switchable foldamers. Chemistry - A European Journal, 17(16): 4540 - 4551.

33. Heinze, K. and Schlenker, M. (2004) Main chain ferrocenyl amides from 1-aminoferrocene-1-carboxylic acid. European Journal of Inorganic Chemistry, 2004(14): 2974 - 2988.

34. Etter, M., Nigar, A., Ali, N. Z., Akhter, Z. and Dinnebier, R. E. (2016). Synthesis, spectroscopic and structural perspective of new ferrocenyl amides. Solid State Science, 55: 29 - 35.

35. Thomas, D. W. and Martell, A. E. (1956). Absorption Spectra of Para-Substituted Tetraphenylporphines1,2. Journal of American Chemical Society, 78(7): 1338-1343.

36. Sax, K. J., Saari, W. S., Mahoney, C. L. and Gordon, J. M. (1960). Preparation and infrared absorption spectra of some phenyl ethers. Journal of Organic Chemistry, 25(9): 1590 - 1595.

37. Dunkers, J. and Ishida, H. (1995). Vibrational assignments of 3-alkyl-3,4-dihydro-6-methyl-2h-1,3benzoxazines in the fingerprint region. Spectrochimica Acta Part A: Molecular and Biomolecular Spectroscopy, 51(6): 1061-1074.

38. Altaf, A. A., Badshah, A., Khan, N., Tahir, M. N. (2010). (4-ferrocenylphenyl)benzamide. Acta Crystallography Section E, 66(7): 831.

39. Han, S.-Y. and Kim, Y.-A. (2004). Recent development of peptide coupling reagents in organic synthesis. Tetrahedron, 60(11): $2447-2467$.

40. Valeur, E. and Bradley, M. (2009). Amide bond formation: Beyond the myth of coupling reagents. Chemical Society Reviews, 38(2): $606-631$.

41. Williams, A. and Ibrahim, I. T. (1981). A new mechanism involving cyclic tautomers for the reaction with nucleophiles of the water-soluble peptide coupling reagent 1-ethyl-3-(3'-(dimethylamino) propyl) carbodiimide (EDC). Journal of the American Chemical Society, 103(24): 7090 - 7095.

42. Xu, S., Held, I., Kempf, B., Mayr, H., Steglich, W. and Zipse, H. (2005). The DMAP-catalyzed acetylation of alcohols - a mechanistic study $($ DMAP $=4$-(Dimethylamino)Pyridine). Chemistry - A European Journal, 11(16): $4751-4757$.

43. Vashist, S. K. (2012). Comparison of 1-ethyl-3-(3-dimethylaminopropyl) carbodiimide based strategies to crosslink antibodies on amine-functionalized platforms for immunodiagnostic applications. Diagnostics, 23 33.

44. Mojarradi, H. (2010). Coupling of substances containing a primary amine to hyaluronan via carbodiimidemediated amidation. Independent Thesis Advanced Level of Professional Degree, Department of Biochemistry and Organic Chemistry, Chemistry, Disciplinary Domain of Science and Technology, Uppsala University. 